China Perspectives

51 | january-february 2004

Varia

\title{
Marie-Claire Bergère, Histoire de Shanghai
}

Paris, Fayard, 2002, 520 p.

Xiaohong Xiao-Planes

\section{(2) OpenEdition}

\section{Journals}

Édition électronique

URL : http://journals.openedition.org/chinaperspectives/792

DOI : 10.4000/chinaperspectives.792

ISSN : 1996-4617

Éditeur

Centre d'étude français sur la Chine contemporaine

Édition imprimée

Date de publication : 1 février 2004

ISSN : 2070-3449

\section{Référence électronique}

Xiaohong Xiao-Planes, « Marie-Claire Bergère, Histoire de Shanghai », China Perspectives [En ligne], 51 january-february 2004, mis en ligne le 23 avril 2007, consulté le 24 septembre 2020. URL : http:// journals.openedition.org/chinaperspectives/792 ; DOI : https://doi.org/10.4000/chinaperspectives. 792

Ce document a été généré automatiquement le 24 septembre 2020

(c) All rights reserved 


\section{Marie-Claire Bergère, Histoire de Shanghai}

Paris, Fayard, 2002, 520 p.

Xiaohong Xiao-Planes

\section{NOTE DE L'ÉDITEUR}

Translated from the French original by Jonathan Hall

1 During the last decade, the former leaders of Shanghai such as Jiang Zemin and Zhu Rongji dominated the scene in Peking, where they represented the open-door policy and the "market economy with Chinese characteristics" before handing over to the "fourth generation" at the Sixteenth Party Congress in November 2002. The same period saw the complete transformation of Shanghai. But has the city really recovered its long lost dynamism? Marie-Claire Bergère's book is timely in this respect and offers answers to this question, by placing it in its historical perspective.

2 Her history of Shanghai covers a period of over 150 years-from its emergence as an open port in 1842 to its development into a partly foreign and partly Chinese metropolis, followed by the period of restrictions imposed under Mao and its present return to expansionism. Her description and analysis of this trajectory in its political, economic, social and cultural ramifications, is supported by a considerable body of archival material, firsthand accounts and other studies, many of which are actually her own previous work. She has also included a large number of contemporary Chinese and foreign eye-witness accounts. Her book provides a comprehensive overview, and raises the fundamental question of the role played by Shanghai in the formation of modern China up to the opening years of the twenty-first century.

3 No contemporary history of Shanghai could avoid paying detailed attention to the complex relations between the city and the foreign concessions. At first the latter were intended to be nothing more than residential areas, but at the time of the Taiping rebellion (1850-1860), they were transformed into de facto colonies outside Chinese 
jurisdiction, on the initiative of the foreign residents and their consuls. The largely Chinese population (98\% of the total in 1910) fell under the control and administration of autonomous authorities, particularly the Shanghai Municipal Council which ran the international concession. For its part, the French concession was organised under the protection of the consul general, and it assumed the same prerogatives. Both concessions established a modern setting, in both the physical and the legal senses of the term, and encouraged a free market economy. This meant that the centre of economic activity shifted from the old Chinese city to the international concession, especially the areas around the Bund. As the concessions provided a window onto Western culture, they influenced the chinese outlook and inspired individual and collective innovations. These included the establishment of public and private enterprises, the opening of new schools, the appearance of a press to serve a large public readership, the creation of a Chamber of Commerce and a Chinese City Council (modelled on the Shanghai Municipal Council), the provision of modern technical equipment and public amenities and services in the Chinese quarters etc. To modernise the country and face the challenge from the West quickly became the dream of the residents of Shanghai.

4 At first the economy was centred on the opium trade, but by the beginning of the twentieth century it turned towards overseas trade in general, as well as finance, property speculation and finally industry. In the author's opinion, Shanghainese capitalism was the consequence of a symbiosis between foreigners and the Chinese, and was not, as current Chinese versions of history would have us believe, "economic aggression organised by foreign governments". In fact, overseas and Chinese capital operated jointly; the Chinese professional associations and the foreign hongs shared both domestic and overseas commercial channels. The Chinese entrepreneurial spirit and their capacity to assimilate was grafted onto the technology and managerial methods brought in by these Westerners. A new generation of Chinese businessmen, trained at home or abroad, was well placed to play a leading role in the industrial miracle of the 1920s. This rapid take-off of Shanghainese capitalism was founded on private initiative, and lasted until 1937 despite the bureaucratic obstacles and depredations of the Nationalist regime. It just about managed to survive under the Japanese occupation, before sinking under the Communist nationalisation programme. It has recently re-emerged, but is struggling to rediscover its former stimulating environment.

5 The population of Shanghai consisted mainly of immigrant communities from the hinterland. They organised themselves into mutual support societies according to their place of origin, and into professional associations, within which there grew up hierarchical structures based on individual financial and material status. The author argues that this social fragmentation, along with the city's greater level of development in comparison with the rest of the country, were the factors which prevented the appearance of a real bourgeois revolution. The author emphasises however, that the existence of these purely sectional solidarities never prevented the different groups from becoming involved in militant nationalism and playing a leading role in the antiimperialist movements. Whenever the nation was threatened, Shanghai became the focal point for spontaneous mobilisations, in which merchants, workers, intellectuals and ordinary people (xiao shimin) all participated. In the period of Nationalist rule, the trade unions continued to organise strikes and to struggle for workers' rights, despite Kuomintang control and infiltration through the secret societies. The bourgeoisie, who 
desired the protection of a strong unified state, followed a line of compromise and negotiation with the Nanking regime, without abandoning their aspirations to freedom and democracy.

6 At the same time, Shanghai was developing a pluralist, pragmatic, commercial and cosmopolitan culture, open to the participation of the masses: the haipai. The architects built neo-classical or Art-deco buildings alongside industrial tenements; offices, hotels and recreational centres cohabited with the lilong, the dwellings of the ordinary people of a city surrounded by squatter areas. Its cultural productions glorified physical appearances, the images of the modern woman, recreation and consumerism. Shanghai gave birth to the Chinese cinema, and its literature drew inspiration from the widest possible range of western trends. Whatever their detractors may say, the haipai founded a new era.

7 In the Maoist period-which has still not been studied much-Shanghai dried up in a number of ways. It became the milch cow of the planned economy, and a pawn in political and ideological struggle. It is only in the last decade that Peking, impelled by the need for reforms, has decided to make it a showcase for the Chinese economy, allowing municipal initiatives in the field of town planning, expansion and receipt of foreign investments. At present, the city has undergone a radical facelift and its denizens are letting themselves go in pursuit of individual happiness and the seductions of a consumer society. This relative liberalisation, which seems to ignore the increasing social polarisation, continues to favour the hold of the single party system and bureaucratic monopoly. History will judge whether China's accession to the WTO and the subsequent development of the country will alter the situation to favour the arrival of new actors on the scene, allowing the metropolis to re-engage with its former fruitful modernising tradition.

8 This is a thoroughly well-documented work, written in a pleasing style by an eminent and passionately interested specialist in Shanghai studies. It will find a welcome place on the bookshelves of the researcher and the broader public alike. 